\title{
Imaging synaptic inhibition throughout the brain via genetically targeted Clomeleon
}

\author{
Ken Berglund ${ }^{1}$, Wolfram Schleich ${ }^{2,3}$, Hong Wang ${ }^{1,4}$, Guoping Feng ${ }^{1}$, William C. Hall ${ }^{1}$, \\ Thomas Kuner ${ }^{2,5}$ and George J. Augustine ${ }^{1, *}$ \\ ${ }^{1}$ Department of Neurobiology, Duke University Medical Center, 3209, Durham, NC 27710, USA \\ ( ${ }^{*}$ author for correspondence; e-mail: georgea@neuro.duke.edu) \\ 2Department of Cell Physiology, Max Planck Institute for Medical Research, Jahnstrasse 29, \\ 69120 Heidelberg, Germany \\ ${ }^{3}$ Present address: Novartis Institutes for BioMedical Research, Novartis Pharma AG, WKL-125.7.17A, \\ $\mathrm{CH}-4002$ Basel, Switzerland \\ ${ }^{4}$ Present address: Department of Cell and Molecular Physiology, University of North Carolina, 10 CB 7545, \\ Chapel Hill, NC 27599, USA \\ ${ }^{5}$ Present address: Institute of Anatomy and Cell Biology, University of Heidelberg, Im Neuenheimer Feld 307, \\ 69120 Heidelberg, Germany
}

Received 11 June 2008; Revised 27 August 2008; Accepted 27 August 2008

Published online 11 October 2008

(c) Springer Science+Business Media, LLC 2008

Here we survey a molecular genetic approach for imaging synaptic inhibition. This approach is based on measuring intracellular chloride concentration $\left(\left[\mathrm{Cl}^{-}\right]_{i}\right)$ with the fluorescent chloride indicator protein, Clomeleon. We first describe several different ways to express Clomeleon in selected populations of neurons in the mouse brain. These methods include targeted viral gene transfer, conditional expression controlled by Cre recombination, and transgenesis based on the neuronspecific promoter, thy1. Next, we evaluate the feasibility of using different lines of thy1::Clomeleon transgenic mice to image synaptic inhibition in several different brain regions: the hippocampus, the deep cerebellar nuclei (DCN), the basolateral nucleus of the amygdala, and the superior colliculus (SC). Activation of hippocampal interneurons caused $\left[\mathrm{Cl}^{-}\right]_{i}$ to rise transiently in individual postsynaptic CA1 pyramidal neurons. $\left[\mathrm{Cl}^{-}\right]_{i}$ increased linearly with the number of electrical stimuli in a train, with peak changes as large as $4 \mathrm{mM}$. These responses were largely mediated by GABA receptors because they were blocked by antagonists of GABA receptors, such as GABAzine and bicuculline. Similar responses to synaptic activity were observed in DCN neurons, amygdalar principal cells, and collicular premotor neurons. However, in contrast to the hippocampus, the responses in these three regions were largely insensitive to antagonists of inhibitory neurotransmitter receptors. This indicates that synaptic activity can also cause $\mathrm{Cl}^{-}$influx through alternate pathways that remain to be identified. We conclude that Clomeleon imaging permits non-invasive, spatiotemporally precise recordings of $\left[\mathrm{Cl}^{-}\right]_{i}$ in a large variety of neurons, and provides new opportunities for imaging synaptic inhibition and other forms of neuronal chloride signaling.

\section{Introduction}

Imaging is the most promising means of determining the activity patterns of neural circuits in the brain.
Neuronal excitation in large populations of neurons has been imaged by voltage-sensitive dyes, $\mathrm{Ca}^{2+}$ indicators, intrinsic signal imaging, and fMRI (Mao et al., 2001; Mrsic-Flogel et al., 2003; Grinvald and 
Hildesheim, 2004; Baker et al., 2005). Even though synaptic inhibition is an essential contributor to neuronal computation, inhibitory circuit activity has been imaged less frequently. Although there are reports of detection of synaptic inhibition via imaging with voltage-sensitive dyes, autofluorescence, $\mathrm{pH}$ indicators, and organic $\mathrm{Cl}^{-}$indicator dyes (Elias et al., 1993; Horikawa et al., 1996; Cohen and Yarom, 2000; Derdikman et al., 2003; Isomura et al., 2003; Ebner et al., 2005), analysis of neural circuits has been limited by the lack of effective techniques for visualizing synaptic inhibition.

Fast synaptic inhibition mainly results from $\mathrm{Cl}^{-}$ fluxes mediated by ionotropic $\gamma$-aminobutyric acid (GABA) and glycine receptors. Due to the low intracellular concentration of chloride $\left(\left[\mathrm{Cl}^{-}\right]_{\mathrm{i}}\right)$, activation of these receptors leads to $\mathrm{Cl}^{-}$influx into neurons. These $\mathrm{Cl}^{-}$fluxes can hyperpolarize the membrane potential or can shunt excitatory transmission without affecting membrane potential, yielding a form of inhibition that is virtually invisible to measurements of membrane potential. However, all inhibitory actions that result from $\mathrm{Cl}^{-}$influx will increase postsynaptic $\left[\mathrm{Cl}^{-}\right]_{\mathrm{i}}$ (Kaila, 1994; Kuner and Augustine, 2000; Marandi et al., 2002; Isomura et al., 2003; Berglund et al., 2006; Jedlička and Backus, 2006). Thus, direct measurement of changes in $\left[\mathrm{Cl}^{-}\right]_{\mathrm{i}}$ could be a powerful means of imaging synaptic inhibition.

Clomeleon is a genetically encoded fluorescent indicator that permits optical determination of $\left[\mathrm{Cl}^{-}\right]_{\mathrm{i}}$ (Kuner and Augustine, 2000). Because Clomeleon is based on fluorescence resonance energy transfer (FRET), Clomeleon allows ratiometric measurement of absolute $\left[\mathrm{Cl}^{-}\right]_{\mathrm{i}}$. This permits accurate determination of resting $\left[\mathrm{Cl}^{-}\right]_{\mathrm{i}}$ as well as changes in $\left[\mathrm{Cl}^{-}\right]_{i}$ elicited by activation of GABA receptors. Unlike organic $\mathrm{Cl}^{-}$dyes (Verkman, 1990), Clomeleon can be genetically targeted to distinct populations of neurons. These properties make Clomeleon suitable for studying many poorly understood aspects of $\left[\mathrm{Cl}^{-}\right]_{\mathrm{i}}$ regulation, including developmental shifts of $\left[\mathrm{Cl}^{-}\right]_{\mathrm{i}}$, activity-dependent ionic plasticity (Kaila, 1994; Payne et al., 2003), compartmental gradients of $\left[\mathrm{Cl}^{-}\right]_{\mathrm{i}}$ (Derdikman et al., 2003; Szabadics et al., 2006), sensory signal transduction (Reuter et al., 1998), and pathophysiologic mechanisms in a multitude of diseases (Payne et al., 2003; Pond et al., 2006). Most importantly, targeting of Clomeleon to specific populations of neurons could allow selective measurement of synaptic circuitry that inhibits these neurons.
Here, we summarize the use of Clomeleon for imaging $\mathrm{Cl}^{-}$-mediated synaptic inhibition in neuronal networks. Such an approach holds promise for revealing the spatiotemporal patterns of synaptic inhibition in neuronal populations during circuit activity, and should yield fundamental insights into the functions of neuronal networks. To achieve this goal, we have developed several different techniques to express Clomeleon in selected populations of neurons. We first review our recent work with indicator mouse lines expressing Clomeleon under the control of the thy 1 promoter (Feng et al., 2000; Berglund et al., 2006) and Cre recombination technique, which give rise to Clomeleon expression in different neuronal subsets. We also describe in vivo viral transfer of Clomeleon gene to targeted neurons. Finally, using thy 1 transgenic mice with robust expression of Clomeleon, we show that activation of inhibitory synapses produces detectable, transient increases in $\left[\mathrm{Cl}^{-}\right]_{\mathrm{i}}$ in several brain regions. This demonstrates that Clomeleon provides a means of visualizing the dynamics of synaptic inhibition in space and in time. Thus, Clomeleon indicator mouse lines provide powerful tools for measuring $\left[\mathrm{Cl}^{-}\right]_{\mathrm{i}}$ in neurons and, thereby, for visualizing inhibitory circuit activity and other forms of $\mathrm{Cl}^{-}$dynamics.

\section{Methods of expressing Clomeleon in neurons}

To measure synaptic inhibition, Clomeleon must be expressed within neurons and a rich variety of molecular genetic methods can be used for this purpose. The simplest approach to express Clomeleon is through the use of expression plasmids, which can be transfected into cultured neurons on a bulk scale using any standard DNA transfection protocol (e.g., Kuner and Augustine, 2000) or via electroporation (Teruel et al., 1999). To achieve large scale expression of Clomeleon in the intact brain, in vivo electroporation (Inoue and Krumlauf, 2001; Wei et al., 2003) of Clomeleon plasmids can be applied. Plasmid-driven expression of Clomeleon from CMV promoters usually yields high expression levels that provide strong fluorescence signals. While these approaches are useful for a wide range of applications, they lack cellular specificity, often giving rise to expression in both 
neuronal and glial cells. A higher degree of selectivity can be attained with single-cell electroporation of plasmids (Rathenberg et al., 2003; Kitamura et al., 2008), which allows expression in morphologically identified neurons.

A certain degree of control over the selectivity of Clomeleon expression can be attained by combining viral gene transfer with stereotaxic delivery (Wimmer et al., 2004). For example, recombinant adeno-associated virus (AAV) pseudotyped with the AAV-1 and AAV-2 serotype primarily transduces neurons (McCown, 2005). Combined with focal stereotaxic delivery to certain brain areas (Fig. 1a), good spatiotemporal control of Clomeleon expression can be attained (Fig. 1b). In particular, due to the neuron-specific infection of AAV, a strong expression cassette employing the CMV-enhancer-chicken- $\beta$-actin promoter (CBA), WPRE element, and bGH polyadenylation site (Klugmann et al., 2005) allows particularly strong expression of
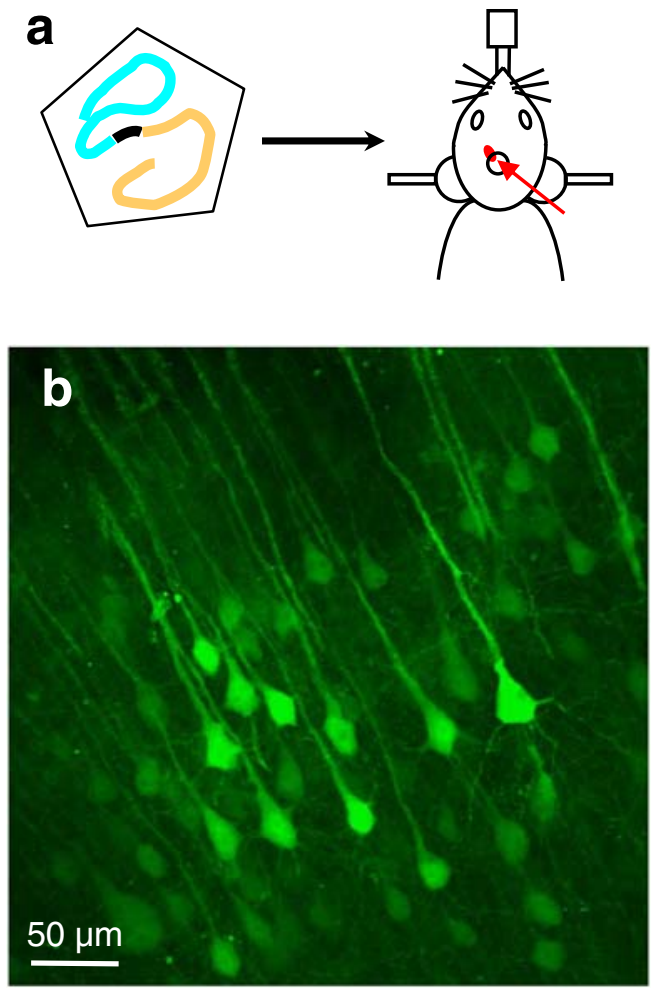

Fig. 1. Stereotaxic delivery of AAV1/2-Clomeleon (a) AAV1/2 containing Clomeleon transgene (left) was delivered to the neocortex of a mouse mounted on a stereotaxic device (right). (b) Clomeleon expression in neocortical layer 5 neurons. Projection of an image stack obtained with confocal microscopy of aldehyde-fixed tissue.
Clomeleon, as illustrated by the Clomeleonexpressing cortical pyramidal cells.

To use Clomeleon to define the physiological characteristics of defined subsets of neurons, Clomeleon must be expressed in genetically defined populations of neurons. We have used three such approaches to achieve selective expression of Clomeleon in defined groups of neurons in mice. The first strategy was based on using the strong neuron-specific promoter, thy 1 (Caroni, 1997; Feng et al., 2000). This promoter preferentially yields expression in projection neurons but has pronounced positional variegation, so that transgene expression is targeted to different populations of projection neurons in each mouse line (Feng et al., 2000). The thy 1 promoter has been successfully used to drive expression of Clomeleon (Fig. 2a) in different regions of the brain (Berglund et al., 2006). Each of the 7 thy $1::$ Clomeleon mouse lines that we have developed shows a unique pattern of Clomeleon expression in the brain (Fig. 2b-d). For example, line CLM11 shows strong Clomeleon expression in the CA1 area of the hippocampus and in neocortical areas (Fig. 2b), line CLM12 shows strong expression in the superior and inferior colliculi (Fig. 2c), and line CLM13 shows intense Clomeleon expression in the dentate gyrus, cerebellar mossy fibers, and piriform cortex (Fig. 2d). At the cellular level, in some areas there was a high density of Clomeleon-expressing neurons, while in other areas these neurons were sparse (Fig. 3a-c).

As will be described in detail below, these thy $1::$ Clomeleon lines are very useful for imaging synaptic inhibition in brain slices (Berglund et al., 2006). In addition, they have already proven useful for a variety of other applications. For example, these Clomeleon transgenic mice have been successfully used for study of $\mathrm{Cl}^{-}$signaling mechanisms in the retina (Duebel et al., 2006), for describing the effects of oxygen deprivation upon $\left[\mathrm{Cl}^{-}\right]_{\mathrm{i}}$ in hippocampal neurons (Pond et al., 2006), and for quantitative measurement of resting $\left[\mathrm{Cl}^{-}\right]_{i}$ in a variety of neuron types (Berglund et al., 2006). The high expression of Clomeleon in these lines, in combination with in vivo two-photon microscopy (Helmchen and Denk, 2005), has allowed the first visualization of the entire neocortical layer 5 pyramidal neurons in living mice (Fig. 3d). This approach opens the possibility of imaging synaptic inhibition in the cortex of intact, behaving mice. 
Fig. 2. Differential expression of Clomeleon in CLM lines (a) The thy 1 gene and Clomeleon cassette. Clomeleon consists of cyan fluorescent protein (CFP), a linker of 24 amino acid residues (gray), and the yellow fluorescent protein (YFP) Topaz. Partial schematic structure of the thy 1 gene is shown with exons labeled in roman numerals. (b-d) Clomeleon expression in thy $1:$ :Clomeleon mice lines CLM11 (b), CLM12 (c), CLM13 (d). Adapted from Berglund et al. (2006). The diagram (bottom) was adapted from Paxinos and Franklin (2001).
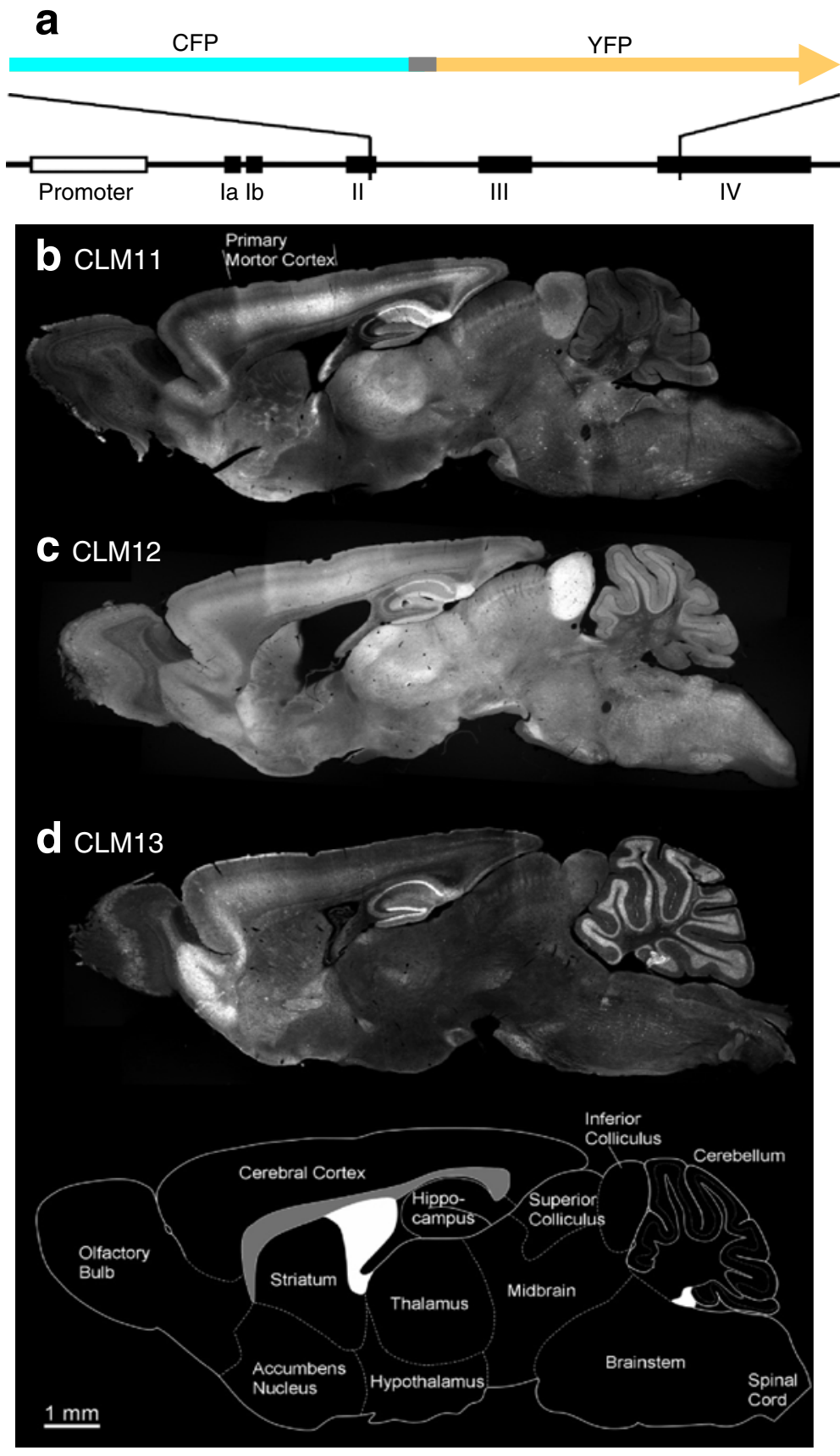

The second line of Clomeleon indicator mice was designed to target Clomeleon expression selectively in genetically identified cell types by harnessing the increasing availability of mouse lines expressing the Cre recombinase in a cell-type specific manner. For this purpose, Clomeleon preceded by a transcriptional stop cassette was targeted into the ROSA26 locus (Soriano, 1999; Srinivas et al., 2001) using homologous recombination (Fig. 4a). When bred with mice expressing the Cre recombinase in a specific set of neurons, the transcriptional stop cassette is excised by the Cre recombinase, unleashing transcription of the Clomeleon cDNA. Hence, this universal Clomeleon 

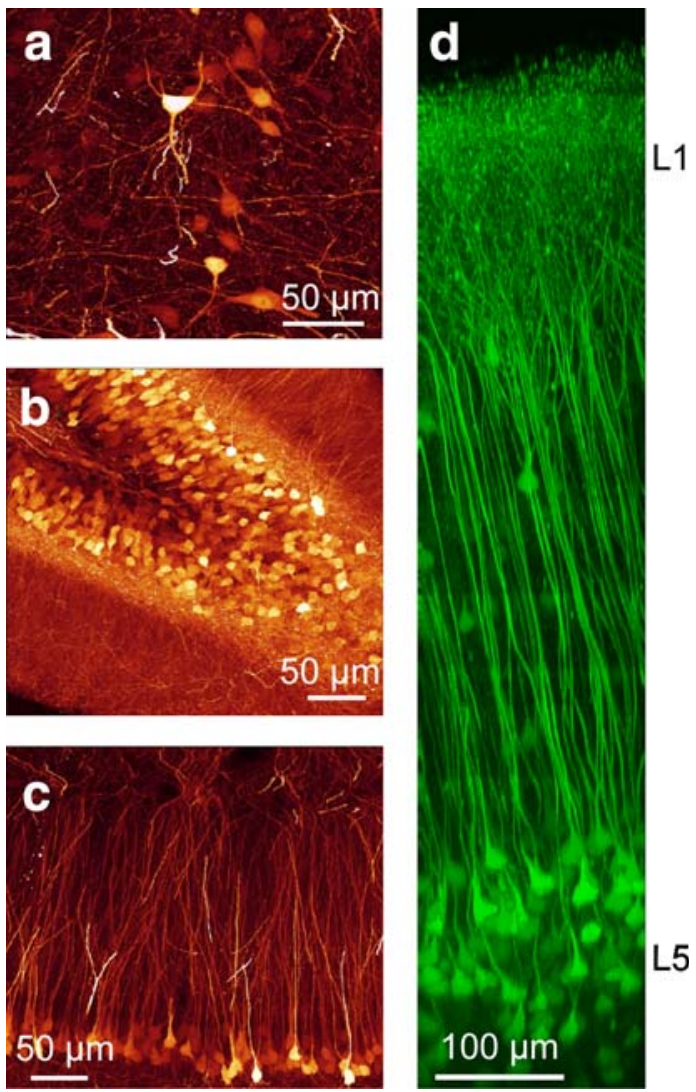

Fig. 3. Clomeleon expression on the cellular level in thy $1:$ :Clomeleon mice (a-c) Expression in the hippocampus. (a) hilus, (b) dentate gyrus, (c) CA1 area. Confocal microscopic images of aldehyde-fixed tissue. Reproduced from Berglund et al. (2006). (d) Neocortical layer 5 (L5) neurons were reconstructed from serial images obtained from the brain surface (L1) with in vivo two-photon microscopy (in collaboration with Fritjof Helmchen, Max-Planck-Institute for Medical Research).

indicator mice line (UniAct-Clomeleon) allows specific expression of Clomeleon in cell populations that are specified by the cellular pattern of Cre recombinase expression (Fig. 4b). For example, Clomeleon can be expressed in gonadotropin releasing hormone $(\mathrm{GnRH})$-releasing neurons of the hypothalamus (Fig. 4c), a very sparse population of cells difficult to identify without an appropriate marker (Spergel et al., 1999). Unfortunately, the ROSA26 promoter yields rather low levels of Clomeleon expression in neurons, making intensity-based ratiometric imaging difficult. However, Clomeleon expression is sufficient for two-photon lifetime imaging of the cyan donor fluorescence (Jose et al., 2007), allowing imaging of $\left[\mathrm{Cl}^{-}\right]_{i}$ with excellent background separation (data not shown).
A third strategy for obtaining population-specific Clomeleon expression in neurons utilizes the same transcriptional stop cassette described above for the UniAct-Clomeleon mice, but places this cassette in an AAV vector (Fig. 5a). This approach allows very high levels of Clomeleon expression to be driven by the CBA cassette, while cell-type specific expression is provided by the selective targeting of Cre recombinase. For example, we have injected this AAV-1/2-STOPflox-Clomeleon virus into the cortex of mice that express Cre under the control of the $\mathrm{Ca}^{2+} /$ calmodulin dependent protein kinase type II (CaMKII) promoter, thereby restricting Clomeleon expression to neurons that also express CaMKII (Mantamadiotis et al., 2002). In this case, Clomeleon is expressed only in the cortical pyramidal cells that are known to express CaMKII (Fig. 5b). Due to the strong expression of Clomeleon, intensity-based ratiometric imaging can be conveniently employed. Furthermore, injection of very small amounts of virus can yield sparse expression in only a few neurons, providing good contrast that permits measurements of $\left[\mathrm{Cl}^{-}\right]_{\mathrm{i}}$ in the fine processes of individual neurons, without the need for confocal or two-photon microscopy.

In conclusion, these different strategies for expressing Clomeleon enable several ways to use Clomeleon to measure $\left[\mathrm{Cl}^{-}\right]_{\mathrm{i}}$ in subsets of neurons.

\section{Using Clomeleon to image synaptic inhibition in the hippocampus}

To evaluate the capacity of Clomeleon to image synaptic inhibition, we prepared brain slices from several lines of thy $1::$ Clomeleon transgenic mice. Mouse lines were chosen that exhibited expression in various brain areas, including the hippocampus, the cerebellum, the amygdala, and the superior colliculus (SC). The results we obtained from the hippocampus have been reported recently and a detailed description of these results, along with details of the experimental procedures, can be found in Berglund et al. (2006).

Changes in $\left[\mathrm{Cl}^{-}\right]_{i}$ associated with synaptic inhibition in the hippocampus were imaged in hippocampal slices prepared from the CLM1 line; in this line, most CA1 pyramidal cells express Clomeleon robustly (Fig. 3c; Pond et al., 2006). 


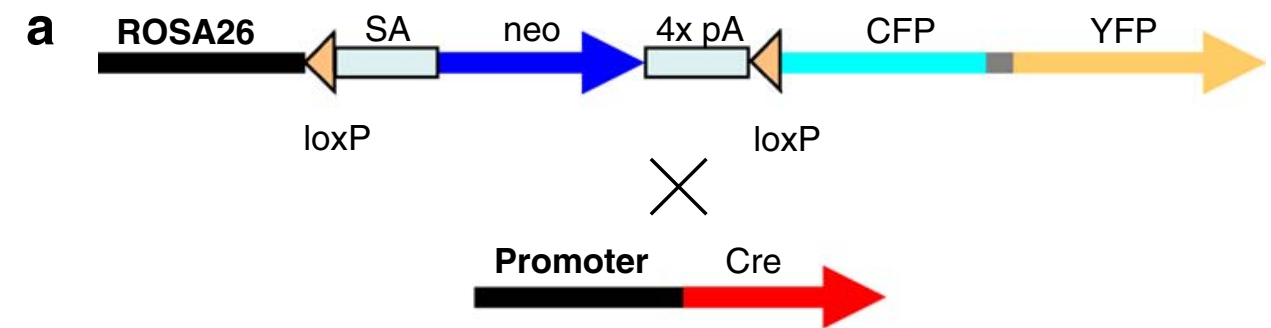

ROSA26

b
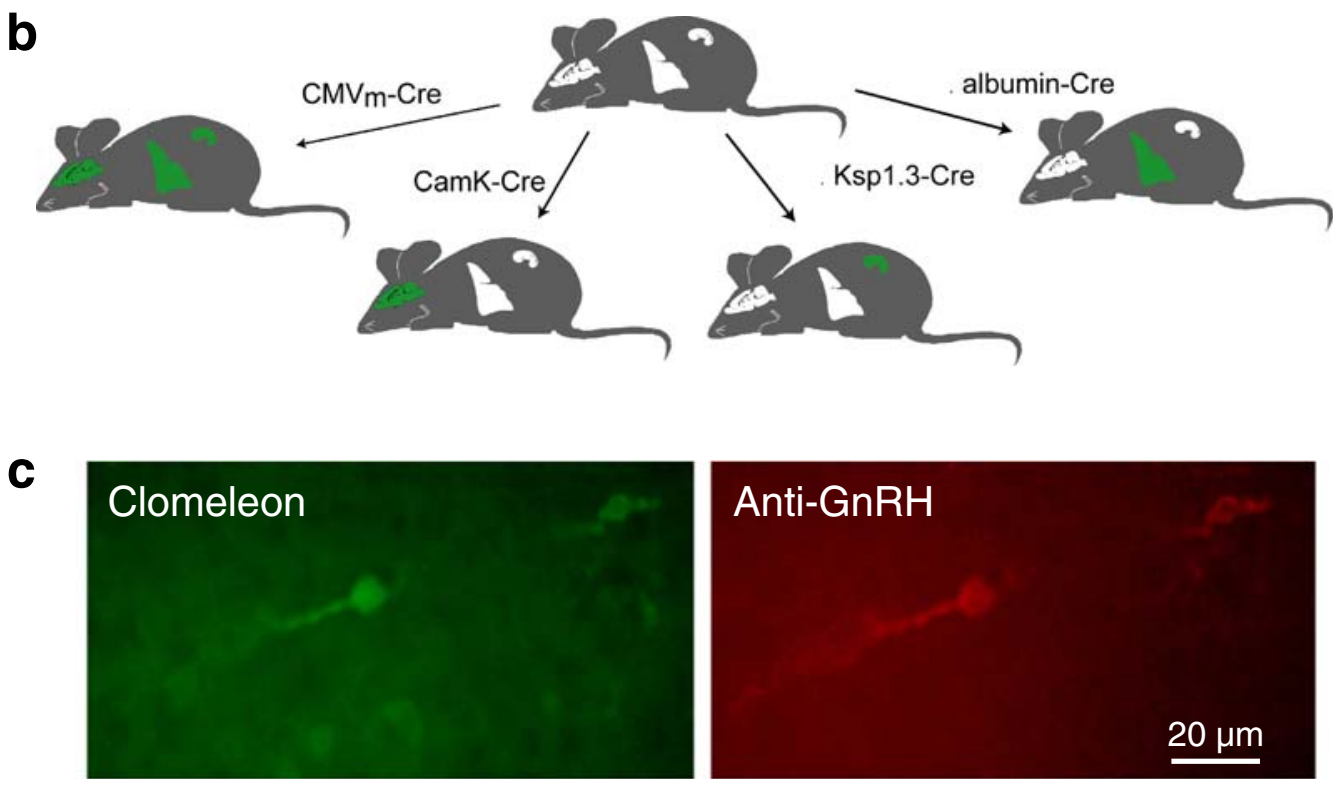

Fig. 4. UniAct-Clomeleon mouse line (a) ROSA26 promoter and transcriptional stop cassette (SA, neo, and 4xpA) flanked by loxP sites (top). In cells expressing Cre under a cell type-specific promoter (center), Clomeleon (CFP in blue and YFP in yellow) expression is activated (bottom). (b) Principle of universally activatable indicator mouse lines with Cre mouse lines with different promoters, such as CMVm (CMVm-Cre), $\mathrm{Ca}^{2+}$ /calmodulin dependent kinase (CamK-Cre), Ksp-cadherin (Ksp1.3-Cre), and albumin (albumin-Cre). (c) Mating a UniAct-Clomeleon mouse with a $\mathrm{GnRH}$-Cre mouse resulted in Clomeleon expression (left) in hypothalamic $\mathrm{GnRH}$ neurons as shown in immunostaining against $\mathrm{GnRH}$ (right).

The hippocampus was chosen as a starting point because the local inhibitory circuits formed between GABAergic interneurons and CA1 pyramidal neurons have been well characterized (Freund and Buzsáki, 1996; Somogyi and Klausberger, 2005). These interneurons were stimulated with an extracellular electrode that was placed at the distal part of the pyramidal cell apical dendrites. A glutamate receptor antagonist, kynurenic acid (2$3 \mathrm{mM}$ ), was added to the extracellular solution to suppress excitatory synaptic transmission and allow study of inhibitory synaptic transmission in isolation.

Under these conditions, Clomeleon detected increases in $\left[\mathrm{Cl}^{-}\right]_{\mathrm{i}}$ in all layers of the CA1 area following stimulation of interneurons (Fig. 6). 

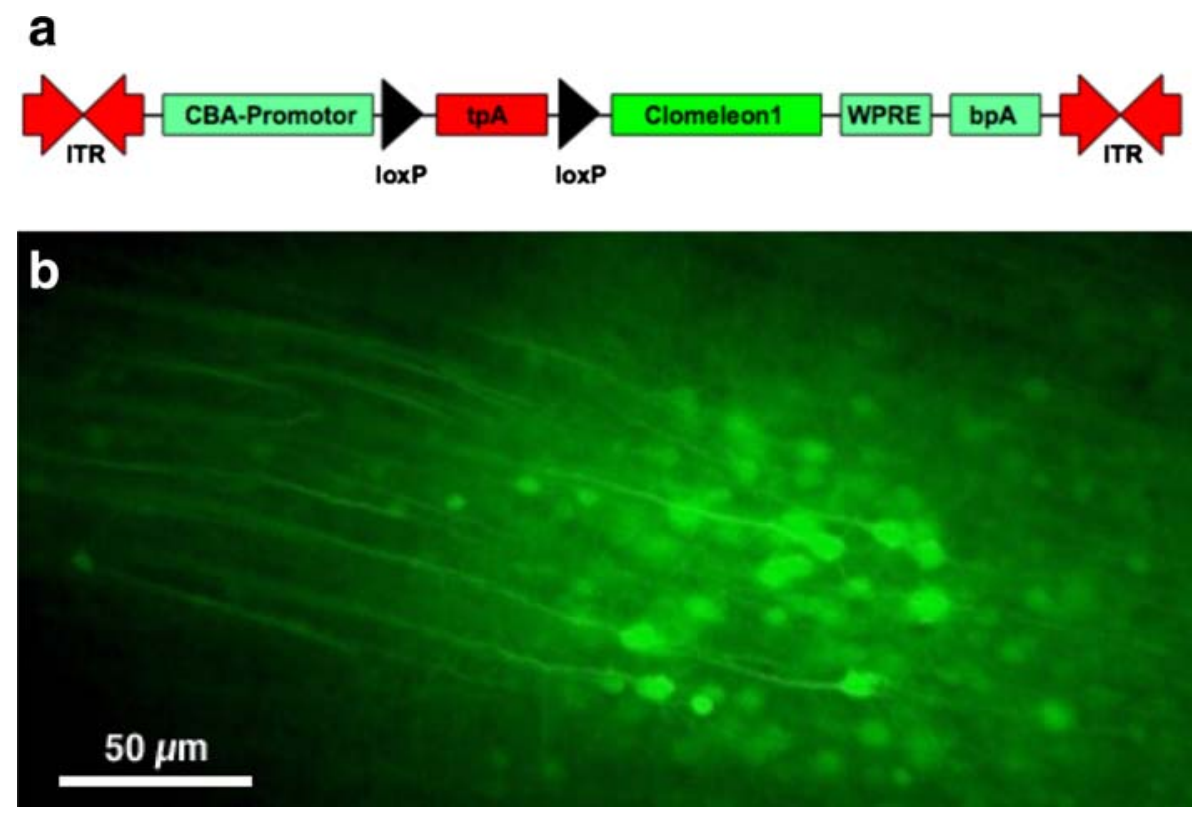

Fig. 5. Clomeleon expression by combination of adenovirus and Cre recombinase technique (a) Structure of STOPflox-Clomeleon, which was integrated into AAV1/2. (b) Stereotaxic injection of AAV1/2-STOPflox-Clomeleon into a CaMKII-Cre mouse resulted in Clomeleon expression in neocortical layer 5 neurons. A wide-field epifluorescence image was obtained in live slice preparation.

Because Clomeleon was expressed only in the CA1 neurons, we could be certain that these responses were generated exclusively by the pyramidal cells. To control the amount of inhibition, the number of stimulus pulses was varied (Fig. 6a-d). Because the resulting changes in $\left[\mathrm{Cl}^{-}\right]_{\mathrm{i}}$ had complex temporal and spatial properties, we first integrated these signals over the entire area of activity to eliminate the spatial dimensions and focus on the time course of the responses. In all cases, responses reached a peak soon after the end of the train of inhibitory postsynaptic potentials (IPSP) and decayed over the next 30-60 s (Fig. 6e). This indicates that the time course of $\left[\mathrm{Cl}^{-}\right]_{\mathrm{i}}$ removal is relatively slow and independent of load over the range considered here. Importantly, the peak amplitude of the $\left[\mathrm{Cl}^{-}\right]_{\mathrm{i}}$ changes increased in direct proportion to the number of stimulus pulses and to the amount of $\mathrm{Cl}^{-}$that entered the postsynaptic pyramidal cells, as determined by voltage-clamp measurements of postsynaptic current (Berglund et al., 2006). Thus, Clomeleon signals provide a linear readout of synaptic inhibition.

To identify the origins of these responses, we first examined their sensitivity to the specific GABA $_{A}$ antagonist, GABAzine (SR95531; $\left.10 \mu \mathrm{M}\right)$.
This drug reduced the responses by $87 \pm 2 \%$ (mean \pm SEM, $n=7$ ), although in 5 out of 14 cells there was little effect of GABAzine treatment (Berglund et al., 2006). We next examined their sensitivity to external $\mathrm{Ca}^{2+}$, which is required for synaptic release of GABA (Duarte et al., 1993). $\mathrm{Ca}^{2+}$ removal reversibly blocked the stimulusevoked changes in $\left[\mathrm{Cl}^{-}\right]_{i}$ in all six slices (Fig. 6f). These results demonstrate that Clomeleon can detect the changes in $\left[\mathrm{Cl}^{-}\right]_{\mathrm{i}}$ resulting from the release of GABA from presynaptic interneurons that activate $G A B A_{A}$ receptors on the postsynaptic CA1 pyramidal neurons.

To characterize the spatiotemporal dynamics of these inhibitory synaptic responses, a line scan was generated that displays the magnitude of $\left[\mathrm{Cl}^{-}\right]_{i}$ changes as a function of both space and time. The line scan measurement shown in Fig. 7a was made from the region indicated by the white rectangle in Fig. $6 \mathrm{~d}$. The area of analysis covered several compartments within the CA1 region, including the distal parts of pyramidal cell apical dendrites (in the stratum lacunosum-moleculare), the proximal parts of apical dendrites (in the stratum radiatum), the pyramidal cell bodies (in stratum pyramidale), and the basal dendrites (in stratum oriens). The resting $\left[\mathrm{Cl}^{-}\right]_{i}$ in each compartment was similar: 

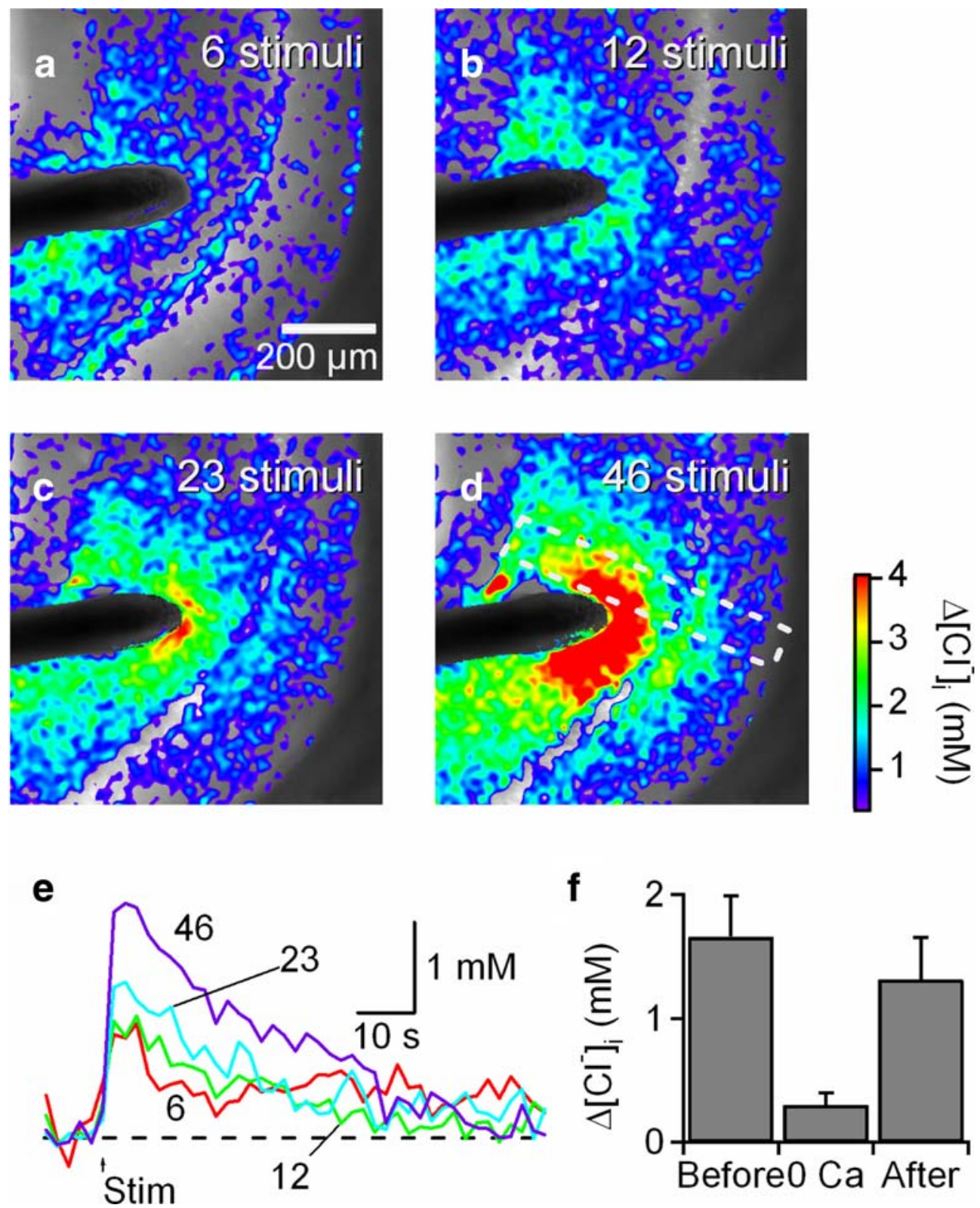

Fig. 6. $\mathrm{Cl}^{-}$transients elicited by synaptic stimulation in the hippocampal $\mathrm{CA} 1$ (a-d) Images showing $\mathrm{Cl}^{-}$changes (pseudo-color) superimposed on YFP fluorescence (gray scale) measured in CLM1 hippocampal slice (P16). The slice was oriented so that the stratum lacunosum-moleculare/radiatum (apical dendrites) is to the left, the stratum pyramidale (somata) is at the center, and the stratum oriens (basal dendrites) is to the right. A train of brief electrical stimuli $(800 \mu \mathrm{A} ; 23 \mathrm{~Hz})$ was delivered by the electrode (black) for $250 \mathrm{~ms}(6 \mathrm{stimuli}$, a), for $500 \mathrm{~ms}$ ( 12 stimuli, b), for $1 \mathrm{~s} \mathrm{(23} \mathrm{stimuli,} \mathrm{c),} \mathrm{and} 2 \mathrm{~s}$ (46 stimuli, d). $\mathrm{Cl}^{-}$was imaged every $2 \mathrm{~s}$ and repeated 4 times for each duration for averaging. The region within the white dotted rectangle was used for further analysis in Fig. 7. (e) Changes in $\left[\mathrm{Cl}^{-}\right]_{i}$ averaged over the whole CA1 in the field shown in a-d. The arrow (Stim) depicts the onset of electrical stimulation. (f) Reversible decrease of $\mathrm{Cl}^{-}$response in nominally $\mathrm{Ca}^{2+}$-free solution. The duration of the train was $1 \mathrm{~s}$ (23 stimuli). Mean \pm SEM of six experiments. Reproduced from Berglund et al. (2006). 
a
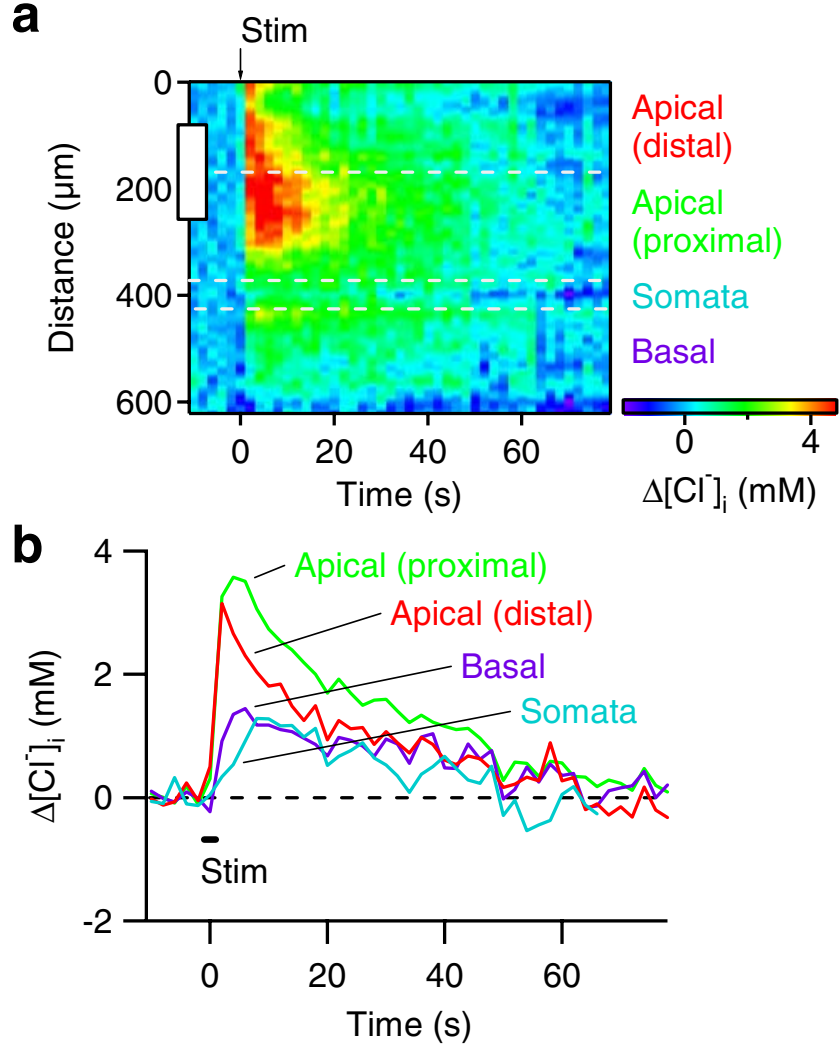
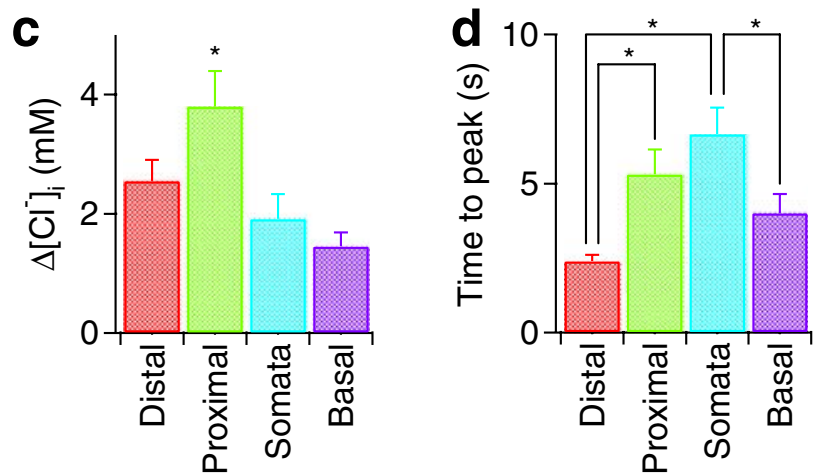

Fig. 7. Spatiotemporal profiles of $\mathrm{Cl}^{-}$transients (a) A line-scan of $\left[\mathrm{Cl}^{-}\right]_{i}$ changes across the layers of CA1. The area of analysis is indicated by the white dotted rectangle in Fig. $6 \mathrm{~d}$ and resting $\left[\mathrm{Cl}^{-}\right]_{\mathrm{i}}$ before stimulation was subtracted to show relative changes caused by stimulation

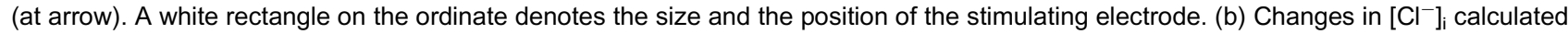
from each layer. Trace colors correspond to those of labels in a. Duration of $2 \mathrm{~s}$ stimulus train is depicted as a line (Stim). (c) Peak magnitude of $\left[\mathrm{Cl}^{-}\right]_{i}$ changes in the four compartments of pyramidal cells in each layer. Mean $\pm \mathrm{SEM}$ of seven experiments. ${ }^{*}$ denotes a significant difference from the rest by ANOVA followed by Newman-Keuls test $\left({ }^{*} P<0.05\right)$. (d) Time to peak of $\left[\mathrm{Cl}^{-}\right]_{\mathrm{i}}$ changes in the same four compartments of pyramidal cells. * denotes a significant difference, as determined by ANOVA followed by Newman-Keuls test $\left({ }^{*} P<0.05\right)$. Reproduced from Berglund et al. (2006).

$5.7 \pm 1.6 \mathrm{mM}$ in distal apical dendrites; $10.3 \pm 3.2 \mathrm{mM}$ in proximal apical dendrites; $5.0 \pm 4.8 \mathrm{mM}$ in somata; and $8.0 \pm 3.7 \mathrm{mM}$ in the basal dendrites (mean \pm SEM, $n=7$ ).
Although resting $\left[\mathrm{Cl}^{-}\right]_{\mathrm{i}}$ tended to be higher in pyramidal cell dendrites than in the somata of these cells, this difference was not significant (ANOVA, $P>0.5$ ). 
$\left[\mathrm{Cl}^{-}\right]_{\mathrm{i}}$ changes associated with synaptic inhibition were largest in the apical dendrites of CA1 neurons, which was the location closest to the site of stimulation. The time course of these changes varied across compartments, as can be seen most clearly when plots of $\left[\mathrm{Cl}^{-}\right]_{i}$ changes over time within each compartment were superimposed (Fig. 7b). While $\left[\mathrm{Cl}^{-}\right]_{i}$ changes in the distal part of apical dendrites rose rapidly and reached a maximum at the end of the train of stimuli, $\left[\mathrm{Cl}^{-}\right]_{i}$ rose more slowly in basal dendrites and in the proximal part of apical dendrites (Fig. $7 \mathrm{~b}$ ). The $\left[\mathrm{Cl}^{-}\right]_{i}$ rise was slowest in somata, probably due to slow diffusion of $\mathrm{Cl}^{-}$from the dendrites and/or from the surface membrane of the cell bodies.

A summary of the measurements of the peak amplitude and the time to peak for seven experiments is shown in Fig. 7c and d. These measurements show that the $\left[\mathrm{Cl}^{-}\right]_{i}$ changes associated with synaptic inhibition of CA1 pyramidal cells were largest and fastest in the apical dendrites but were smaller and slower in the somata and in the basal dendrites. These differences presumably reflect differences in the location of active inhibitory synapses on the pyramidal cells, in the surface-tovolume ratio of the different compartments and in the driving force on $\mathrm{Cl}^{-}$(Staley and Proctor, 1999).

In conclusion, these results document that Clomeleon can detect changes in postsynaptic $\left[\mathrm{Cl}^{-}\right]_{\mathrm{i}}$ in hippocampal neurons that are produced by synaptic inhibition mediated by $\mathrm{GABA}_{\mathrm{A}}$ receptors. These results establish the utility of Clomeleon transgenic mice for imaging synaptic inhibition in the brain.

\section{Clomeleon imaging of inhibition in other brain regions}

To determine whether Clomeleon offers a general means of visualizing inhibitory circuitry, we prepared slices from brain regions other than the hippocampus. One place we examined was the deep cerebellar nuclei (DCN), which is the major output of the cerebellum. The principal cells of the DCN are glutamatergic and receive converging input from the GABAergic Purkinje cells that reside in the cerebellar cortex (Chan-Palay et al., 1979; Telgkamp and Raman, 2002). They also receive excitatory inputs through collaterals of mossy fibers and climbing fibers (Mihailoff, 1993; Shinoda et al., 2000). Electrophysiological recordings have shown that GABAergic transmission onto DCN neurons depresses very little, even during high-frequency activation of Purkinje cells (Telgkamp and Raman, 2002; Telgkamp et al., 2004). This is an advantage for detecting the changes in $\left[\mathrm{Cl}^{-}\right]_{\mathrm{i}}$ associated with synaptic inhibition. In addition, these neurons receive local inhibition from GABA/glycinergic interneurons (Kawa, 2003).

The DCN has three major subdivisions: medial, interposed, and lateral nuclei. In lines CLM1 (Fig. 8a and b) and CLM13 (Fig. 8c), Clomeleon was expressed in all three DCN nuclei. Clomeleon fluorescence could be observed in neurons with large, round cell bodies and multiple dendrites, which are characteristics of the DCN principal cells (Fig. 8b). The resting $\left[\mathrm{Cl}^{-}\right]_{\mathrm{i}}$ in these cells was $8.3 \pm 0.9 \mathrm{mM}$ (mean \pm SEM, $n=34$ ). To activate the Purkinje cell-principal cell inhibitory synapses, a train of electrical stimuli was applied at $100 \mathrm{~Hz}$ for $6 \mathrm{~s}$. This approximates the high frequency, tonic firing of Purkinje cell simple spikes (Thach, 1968; Llinás and Sugimori, 1980). These stimuli were delivered to Purkinje cell axons through a glass electrode that was placed in the white matter of a nearby lobule. Such stimulation produced a transient increase in $\left[\mathrm{Cl}^{-}\right]_{\mathrm{i}}$ in most Clomeleon-positive cells (Fig. 8c). The magnitude of these responses became smaller as the distance between the cells and the stimulating electrode was increased, presumably due to the divergence of Purkinje cell axons over distance.

In both their amplitude and their time course, these responses (Fig. 8d) resembled those found in the hippocampus (Figs. 6e and 7b). Remarkably, the $\mathrm{Cl}^{-}$transients recorded from DCN neurons usually were not blocked by the GABA receptor blocker GABAzine $(10 \mu \mathrm{M})$, or by a mixture of GABAzine plus the glycine receptor antagonist, strychnine $(1 \mu \mathrm{M}$; Fig. $8 \mathrm{~d})$. This indicates that the main source of $\mathrm{Cl}^{-}$in these cases was neither GABA receptors nor glycine receptors. In a few cases (6 out of 23 experiments), the stimulusinduced changes in $\left[\mathrm{Cl}^{-}\right]_{\mathrm{i}}$ were reduced by GABAzine, indicating that these responses must arise from inhibitory synaptic activity. To further identify the nature of the responses in DCN, the glutamatergic antagonist, kynurenic acid $(2 \mathrm{mM})$ was also applied, but also was found to have no effect on the $\mathrm{Cl}^{-}$transients (Fig. 8d, KA). Thus, in contrast to the hippocampus, $\mathrm{Cl}^{-}$transients in $\mathrm{DCN}$ were 

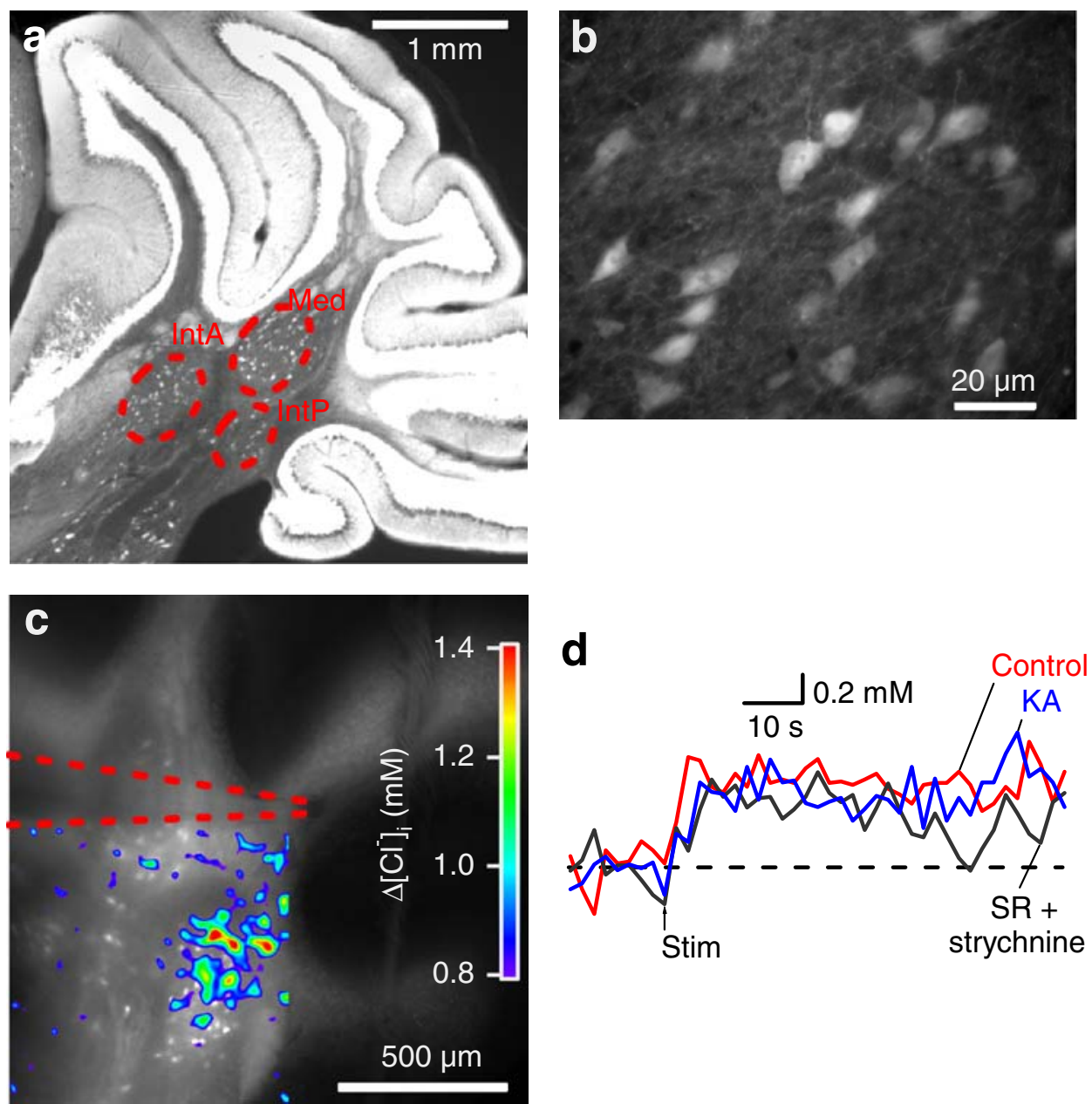

Fig. 8. Clomeleon response in DCN (a) Clomeleon was expressed in the medial (Med), the anterior (IntA), and the posterior part (IntP) of the interposed nuclei. A sagittal section was cut from CLM1 cerebellum. Note robust expression of Clomeleon in granule cells in the cerebellar cortex. (b) Clomeleon was expressed in large and round cells, indicative of glutamatergic principal cells, in the lateral nucleus of the cerebellum of CLM1. (c) Electrical stimulation to the corticonuclear tract in the 8th lobule (dotted red lines) elicited $\left[\mathrm{Cl}^{-}\right]_{\mathrm{i}}$ increase in the posterior interposed nucleus. Four images were photomontaged to generate a raw YFP-fluorescent image in gray scale. For $\left[\mathrm{Cl}^{-}\right]_{\mathrm{i}}$ change during stimulation shown in pseudo-color scale, only the lower-left quadrant was imaged. The image shown was acquired right after the stimulus. The experiment was done in P18 CLM13 mouse, which lacked granule cell expression. (d) Time course of $\left[\mathrm{Cl}^{-}\right]_{i}$ changes shown in c before (Control), during GABAzine and strychnine (SR + strychnine), and during kynurenic acid (KA) application. The arrow (Stim) depicts the onset of electrical stimulation $(140-\mu \mathrm{A}$ pulses at $100 \mathrm{~Hz}$ for $6 \mathrm{~s})$. Average of three trials in each condition.

mediated by mechanisms other than flux of $\mathrm{Cl}^{-}$ associated with GABA or glycine receptors. They also are not mediated by activation of postsynaptic glutamatergic receptors.

We next examined inhibitory synaptic transmission in the amygdala. The amygdaloid complex also consists of several subdivisions, and neurons within these subdivisions were observed to express Clomeleon in several mouse lines. In line CLM1, we found that Clomeleon was expressed exclu- sively in neurons within the basolateral nucleus (BLA, Fig. 9a and b). The BLA is the main input nucleus of the amygdala and receives converging inputs from several sensory systems. There are two major classes of neurons in BLA: glutamatergic principal cells, which are pyramidal in shape, and GABAergic interneurons. In CLM1, Clomeleonpositive neurons had large pyramid-shaped somata and presumably were the principal cells (Fig. 9c), consistent with the preferential targeting 



Fig. 9. Clomeleon response in the basolateral nucleus of the amygdala (a) A coronal section from CLM1 showing Clomeleon expression in the basolateral nucleus of the amygdala. (b) A diagram showing the amygdaloid complex. LA: the lateral nucleus, BLA: the basolateral nucleus, BMA: the basomedial nucleus, CeA: the central nucleus of the amygdala. Pir: the piriform cortex, CPu: the caudate putamen. Adapted from Paxinos and Franklin (2001). (c) Clomeleon was found in putative pyramidal cells in a sagittal section from another CLM1 brain. $(\mathrm{d}-\mathrm{h})$ Electrical stimulation to $\mathrm{LA}$ (red circle) elicited $\left[\mathrm{Cl}^{-}\right]_{\mathrm{i}}$ increase in BLA. $\left[\mathrm{Cl}^{-}\right]_{\mathrm{i}}$ change during stimulation shown in pseudo-color scale was overlaid on raw YFP fluorescence in gray scale. The image shown was acquired right after the stimulus. The experiment was done in P32 CLM1 mouse. (d) A response before application, (e) during bicuculline, (f) kynurenic acid, (g) bicuculline and kynurenic acid, and (h) recovery after application. (i) Time course of $\left[\mathrm{Cl}^{-}\right]_{i}$ changes shown in the four conditions. The arrow (Stim) depicts the onset of electrical stimulation $(30-\mu \mathrm{A}$ pulses at $50 \mathrm{~Hz}$ for $2 \mathrm{~s})$. Average of three trials in each condition. (j) Peak magnitude of $\left[\mathrm{Cl}^{-}\right]_{i}$ changes in the five conditions shown in $\mathrm{d}-\mathrm{h}$. Mean \pm SEM of three experiments. ${ }^{*}$ denotes a significant difference from the rest or between the two conditions by ANOVA followed by Newman-Keuls test $\left({ }^{*} P<0.05\right)$. 
of projection neurons by the thy 1 promoter. Clomeleon imaging revealed that the resting $\left[\mathrm{Cl}^{-}\right]_{\mathrm{i}}$ in these cells was $8.9 \pm 0.6 \mathrm{mM}$ (mean $\pm \mathrm{SE}, n=3$ ).

To activate the inhibitory inputs that innervate these cells, we positioned our stimulating electrode within the lateral nucleus of the amygdala (LA). This site was chosen because stimulation here should activate principal-cell axons that excite the GABAergic interneurons of the BLA, yielding a disynaptic inhibitory response (Pitkänen et al., 1995; Sah et al., 2003). Stimulation ( $50 \mathrm{~Hz}$ for $2 \mathrm{~s}$ ) of LA caused widespread $\left[\mathrm{Cl}^{-}\right]_{\mathrm{i}}$ changes in BLA neurons (Fig. 9d), which were similar in time course and magnitude to the inhibitory responses measured in hippocampus and DCN (Fig. 9i). These responses could be reversibly suppressed by the glutamate receptor antagonist, KA (Fig. 9f and h), consistent with the predicted disynaptic nature of the inhibitory responses. However, application of a $\mathrm{GABA}_{\mathrm{A}}$ antagonist, bicuculline, did not block these $\left[\mathrm{Cl}^{-}\right]_{\mathrm{i}}$ changes. This again indicates that the fluxes of $\mathrm{Cl}^{-}$ responsible for these responses are coming from sources other than GABA receptors. In fact, bicuculline augmented the $\left[\mathrm{Cl}^{-}\right]_{\mathrm{i}}$ responses (Fig. 9e); this presumably occurs because block of inhibition increased the amount of excitatory drive onto the presynaptic BLA interneurons.

Finally, we also examined synaptic $\left[\mathrm{Cl}^{-}\right]_{\mathrm{i}}$ responses in the SC, a brain region whose inhibitory circuits help transform sensory information into motor output that drives eye movements (Katsuta and Isa, 2003). In the CLM1 mouse line, there was a sparse distribution of Clomeleon-expressing premotor neurons in the premotor intermediate layers (Fig. 10a). These cells had a resting $\left[\mathrm{Cl}^{-}\right]_{i}$ of $7.0 \pm 0.3 \mathrm{mM}$ (mean \pm SEM, $n=15$ ).

To activate inhibitory circuitry, brief trains of electrical stimuli ( $20 \mathrm{~Hz}$ for $0.2-2 \mathrm{~s}$ ) were applied to a pretectal area just rostral to the SC. Stimulation in this area would be expected to evoke both monosynaptic inhibitory inputs to the collicular neurons via pretectal-collicular pathways and disynaptic inhibitory inputs mediated by excitatory pathways that pass through the pretectum and terminate on inhibitory interneurons in the SC (Nabors and Mize, 1991; Prochnow et al., 2007). In fact, electrical stimulation in this layer increased $\left[\mathrm{Cl}^{-}\right]_{\mathrm{i}}$ (Fig. 10b). These responses were blocked by the calcium channel blocker, cadmium (10 $\mu \mathrm{M} ; n=7)$, indicating that they result from synaptic activity. However, this change was not significantly (paired Student's $t$-test, $P>0.4, n=20$ ) reduced by GABAzine

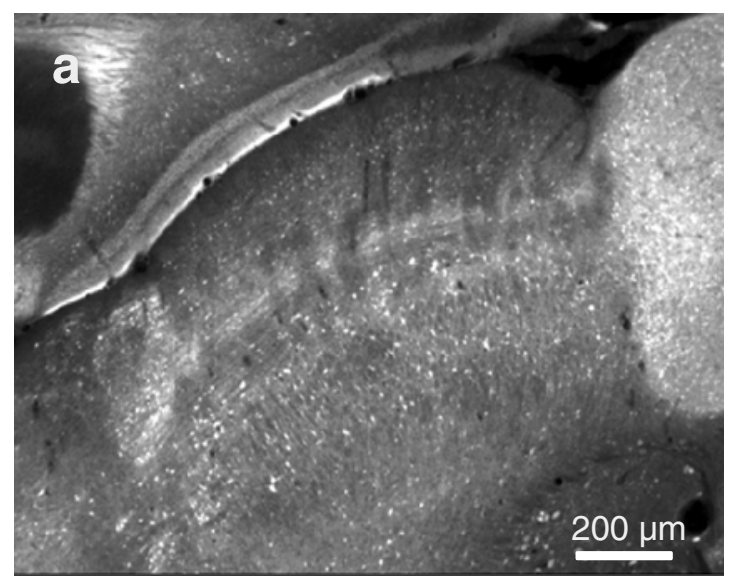

b
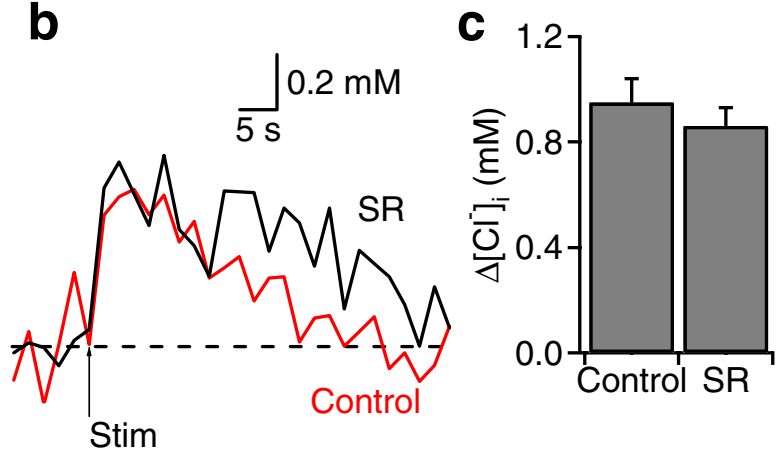

Fig. 10. Clomeleon response in the superior colliculus (a) Clomeleon expression in the superior colliculus in a sagittal section from CLM1. (b) Time course of $\left[\mathrm{Cl}^{-}\right]_{\mathrm{i}}$ changes before (Control) and during application of GABAzine (SR). The arrow (Stim) depicts the onset of electrical stimulation $(400-\mu \mathrm{A}$ pulses at $20 \mathrm{~Hz}$ for $1 \mathrm{~s}$ ). Average of three trials in each condition. (c) Peak magnitude of $\left[\mathrm{Cl}^{-}\right]_{\mathrm{i}}$ changes in the two conditions. Mean \pm SEM of 20 experiments.

(Fig. 10c). Parallel electrophysiological measurements indicated that this concentration of GABAzine completely blocked inhibitory postsynaptic currents (IPSCs) elicited by these stimuli, as expected $(n=12)$. In most cases, these responses were not blocked by CNQX, a blocker of AMPA-type glutamate receptors. Thus, similar to the situation in the $\mathrm{DCN}$ and the $\mathrm{BLA},\left[\mathrm{Cl}^{-}\right]_{i}$ changes produced in the $S C$ in response to electrical stimulation were not mediated by $\mathrm{GABA}_{\mathrm{A}}$ receptors.

We performed additional experiments to identify the sources of $\mathrm{Cl}^{-}$responsible for these responses. Extracellular stimulation would be expected to cause release of both GABA and glutamate, and it is known that transport of both of these 
neurotransmitters is coupled to $\mathrm{Cl}^{-}$fluxes (Wadiche et al., 1995; Richerson and Wu, 2003; Zomot et al., 2007). Thus, we determined whether blockers of these transporters affected the changes in $\left[\mathrm{Cl}^{-}\right]_{\mathrm{i}}$ produced by collicular synaptic activity. A blocker of the GAT1 GABA transporter (NNC711; $10 \mu \mathrm{M})$ had no effect on these signals $(n=7)$. This indicates that the responses are not mediated by $\mathrm{Cl}^{-}$fluxes associated with the GAT1 GABA transporter. To consider the role of $\mathrm{Cl}^{-}$fluxes associated with glutamate transport, we applied threo- $\beta$ benzyloxyaspartate (TBOA), which is a blocker of the EAAT1 glutamate amino acid transporter. While this drug slightly reduced the changes in $\left[\mathrm{Cl}^{-}\right]_{\mathrm{i}}$ produced by synaptic activity $(50 \%, n=7)$, these responses were not eliminated. Thus, while we do not know the source of $\mathrm{Cl}^{-}$, we can conclude that these responses are associated with synaptic activity but do not arise from flux of $\mathrm{Cl}^{-}$through GABA receptors or co-transport with GABA or glutamate.

\section{Conclusions}

We have described different molecular strategies to express Clomeleon in subsets of neurons in the mouse brain. These techniques enhance the versatility of Clomeleon for imaging many different forms of brain activity. Using one of the techniques for selective expression, thy $1::$ Clomeleon transgenic mice, we found that dynamic changes in $\left[\mathrm{Cl}^{-}\right]_{\mathrm{i}}$ resulting from synaptic activity can be detected. In the hippocampus, the changes in $\left[\mathrm{Cl}^{-}\right]_{\mathrm{i}}$ were directly proportional to the amount of synaptic inhibition, indicating that Clomeleon can quantitatively track inhibition. These results demonstrate that Clomeleon provides a novel approach for imaging synaptic inhibition and inhibitory network activity.

In the other brain regions we tested, activation of inhibitory synapses produced changes in $\left[\mathrm{Cl}^{-}\right]_{\mathrm{i}}$ that were not blocked by antagonists of GABA or glycine receptors, indicating an alternative source of $\mathrm{Cl}^{-}$. Even in the hippocampus, where GABAzine usually blocked the $\left[\mathrm{Cl}^{-}\right]_{i}$ changes associated with activation of inhibitory synapses, we occasionally observed incomplete blockade of these responses (Berglund et al., 2006). On the other hand, when synaptic activity was eliminated by $\mathrm{Ca}^{2+}$ removal in the hippocampus or by cadmium treatment in SC, the $\left[\mathrm{Cl}^{-}\right]_{i}$ changes were almost completely blocked. This indicates that synaptic activity is responsible for the $\left[\mathrm{Cl}^{-}\right]_{\mathrm{i}}$ changes. Very similar observations have been made in the hippocampus by imaging $\left[\mathrm{Cl}^{-}\right]_{\mathrm{i}}$ with an organic $\mathrm{Cl}^{-}$indicator dye, MEQ (Isomura et al., 2003). This demonstrates that these signals are genuine changes in $\left[\mathrm{Cl}^{-}\right]_{\mathrm{i}}$ and are not due to changes in $\mathrm{pH}$, to which Clomeleon is also somewhat sensitive (Kuner and Augustine, 2000).

Although the source of $\left[\mathrm{Cl}^{-}\right]_{\mathrm{i}}$ responsible for the responses that were insensitive to GABA receptor antagonists is unclear, our results eliminate several possibilities. While neuronal excitation can cause $\mathrm{Cl}^{-}$influx through voltage- and calciumdependent $\mathrm{Cl}^{-}$channels, as well as other anion channels, the responses recorded in hippocampus, SC, and DCN persisted during treatment with blockers of ionotropic glutamate receptors, the most likely source of excitation during synaptic activity. Thus, we conclude that these responses are not due to activation of such $\mathrm{Cl}^{-}$channels. (Responses in the amygdala were eliminated by such blockers, but this presumably is due to the disynaptic nature of these responses.) Release of GABA and glutamate during synaptic activity is associated with reuptake of these neurotransmitters, which is also coupled to $\mathrm{Cl}^{-}$fluxes. However, our experiments in SC ruled out GABA or glutamate transporters as the sources of $\mathrm{Cl}^{-}$for the responses elicited in this region. Repetitive firing of presynaptic terminals causes accumulation of extracellular $\mathrm{K}^{+}$and intracellular $\mathrm{Na}^{+}$, which could alter the activity of cation-dependent $\mathrm{Cl}^{-}$transporters, such as KCC2 and NKCC1. However, we have found that the GABAzine-insensitive responses recorded in hippocampal neurons were not blocked by furosemide $(300 \mu \mathrm{M})$, an inhibitor of both these transporters, indicating that these cation-dependent $\mathrm{Cl}^{-}$transporters also are not the source of the changes in $\left[\mathrm{Cl}^{-}\right]_{\mathrm{i}}$ produced by synaptic activity (unpublished results). Future studies will be required to identify the sources of $\mathrm{Cl}^{-}$during the changes in $\left[\mathrm{Cl}^{-}\right]$produced by synaptic activity in these regions.

Clomeleon allows the first direct quantification of the changes in postsynaptic $\left[\mathrm{Cl}^{-}\right]$associated with activity of inhibitory synapses. We have found that repetitive activation of inhibitory synapses can increase $\left[\mathrm{Cl}^{-}\right]_{\mathrm{i}}$ by as much as $4 \mathrm{mM}$ in hippocampal pyramidal cells, which represents almost a doubling of $\left[\mathrm{Cl}^{-}\right]_{\mathrm{i}}$ in these cells from its resting level of approximately $5 \mathrm{mM}$. Such accumulation of $\mathrm{Cl}^{-}$ 
during synaptic activity might contribute to synaptic computation by modifying the driving force on subsequent fluxes of $\mathrm{Cl}^{-}$, particularly during repetitive activity (Thompson and Gähwiler, 1989; Isomura et al., 2003; Jedlička and Backus, 2006). This form of ionic plasticity could also apply to depletion of intracellular $\mathrm{Cl}^{-}$(Kuner and Augustine, 2000) during the depolarizing actions of GABA or glycine in early postnatal stages of maturation, a time when $\left[\mathrm{Cl}^{-}\right]_{\mathrm{i}}$ is very high (Ben-Ari et al., 1989; Cherubini et al., 1991; Owens et al., 1996; Berglund et al., 2006). Our results indicate that Clomeleon imaging techniques are suitable for studies of the dynamic changes in $\mathrm{Cl}^{-}$gradients which potentially underlie such forms of ionic plasticity.

In comparison to organic indicator dyes, Clomeleon showed somewhat lower signal-to-noise ratios. This is similar to the case of genetically encoded $\mathrm{Ca}^{2+}$ indicators, which also show poorer signal-to-noise ratios than their organic counterparts (Hasan et al., 2004; Pologruto et al., 2004; Reiff et al., 2005). For example, detecting inhibitory synaptic transmission at a single-cell level requires 15 IPSCs, which is equivalent to $100 \mathrm{pC}$ of $\mathrm{Cl}^{-}$ influx (Berglund et al., 2006). This low sensitivity is partly due to the low $\mathrm{Cl}^{-}$binding affinity of Clomeleon (approximately $90 \mathrm{mM}$; Kuner and Augustine, 2000) relative to the small changes in $\left[\mathrm{Cl}^{-}\right]_{i}$ (at most a $4 \mathrm{mM}$ increase) produced by synaptic activity (Figs. 6 and 7). A second factor is the dynamic range of Clomeleon; the YFP:CFP ratio approximately doubles from the minimum to the maximum (Kuner and Augustine, 2000), which is a smaller range than for organic indicator dyes. A third factor is the need to reduce the intensity of the excitation light to avoid reversible photobleaching (Dickson et al., 1997; Sinnecker et al., 2005), which is more prominent for YFP than for CFP and therefore can cause changes in the YFP:CFP emission ratio of Clomeleon in the absence of $\left[\mathrm{Cl}^{-}\right]_{i}$ changes (Berglund et al., 2005). Efforts to optimize the properties of Clomeleon are underway and should improve these limitations of Clomeleon.

Unlike $\mathrm{Ca}^{2+}, \mathrm{Cl}^{-}$is not buffered by binding proteins, but diffuses freely in cells (Kuner and Augustine, 2000). Thus, the rather slow decay (up to a minute) of $\left[\mathrm{Cl}^{-}\right]_{\mathrm{i}}$ after synaptic stimulation is limited by the kinetics of diffusion and extrusion of $\mathrm{Cl}^{-}$. The time course of these $\mathrm{Cl}^{-}$responses is not limited by the binding and unbinding of $\mathrm{Cl}^{-}$to Clomeleon, which takes approximately $0.5 \mathrm{~s}$ at room temperature. Very similar slow recovery of
$\mathrm{Cl}^{-}$after synaptic stimulation has also been reported by an organic $\mathrm{Cl}^{-}$indicator, MEQ (Isomura et al., 2003). The time course of $\mathrm{Cl}^{-}$removal following the activity of inhibitory synapses is likely to be determined by the slow kinetics of the $\mathrm{Cl}^{-}$ extruder KCC2 (Staley and Proctor, 1999).

Although electrophysiological measurements remain vital to time-resolved recordings at a single-cell level, our study demonstrates that changes in $\left[\mathrm{Cl}^{-}\right]_{\mathrm{i}}$ associated with inhibitory synaptic activity can be detected using Clomeleon as a non-invasive reporter that can be genetically targeted to cell types and subcellular compartments. Further, because Clomeleon images synaptic inhibition, it is possible to obtain spatial information that would be difficult, if not impossible, to obtain via electrical recording techniques. We anticipate that Clomeleon-based imaging of $\left[\mathrm{Cl}^{-}\right]_{i}$ can be used to visualize the spatiotemporal dynamics of inhibitory circuitry with unprecedented resolution. Because we have generated multiple transgenic mice lines that express Clomeleon in many different types of neurons, it is now feasible to visualize the amount and location of synaptic inhibition onto specific subtypes of neurons. These mice should serve as a powerful tool for elucidating the properties of inhibitory synaptic networks both in brain slices and in vivo.

\section{Acknowledgments}

We thank E. Ellison and T. Schweizer for technical assistance, and G. Giese for help with confocal microscopy. This work was partially supported by DFG grant KU1983/1-2 (FOR 577) awarded to T.K., NIMH grants awarded to G.J.A. and G.F., NEI grants to W.C.H., and an Alfred P. Sloan Research Fellowship, a Klingenstein Fellowship Award in the Neuroscience, and a Beckman Young Investigator Award to G.F.

\section{References}

Baker, B. J., Kosmidis, E. K., Vucinic, D., Falk, C. X., Cohen, L. B., Djurisic, M., and Zecevic, D. (2005). Imaging brain activity with voltage- and calcium-sensitive dyes. Cell. Mol. Neurobiol. 25, 245-282. 
Ben-Ari, Y., Cherubini, E., Corradetti, R., and Gaiarsa, J. L. (1989). Giant synaptic potentials in immature rat CA3 hippocampal neurones. J. Physiol. (Lond). 416, 303-325.

Berglund, K., Dunbar, R. L., Lee, P., Feng, G., and Augustine, G. J. (2005). A practical guide: imaging synaptic inhibition with Clomeleon, a genetically encoded chloride indicator. In: Konnerth, A., Yuste, R. (eds.) Imaging in neuroscience and development: a laboratory manual, Cold Spring Harbor Laboratory Press, Cold Spring Harbor, pp. 595-598.

Berglund, K., Schleich, W., Krieger, P., Loo, L. S., Wang, D., Cant, N. B., Feng, G., Augustine, G. J., and Kuner, T. (2006). Imaging synaptic inhibition in transgenic mice expressing the chloride indicator, Clomeleon. Brain Cell. Biol. 35, 207-228.

Caroni, P. (1997). Overexpression of growth-associated proteins in the neurons of adult transgenic mice. J. Neurosci. Methods 71, 3-9.

Chan-Palay, V., Palay, S. L., and Wu, J. Y. (1979). Gamma-aminobutyric acid pathways in the cerebellum studied by retrograde and anterograde transport of glutamic acid decarboxylase antibody after in vivo injections. Anat. Embryol. Berl. 157, 1-14.

Cherubini, E., Gaiarsa, J. L., and Ben-Ari, Y. (1991). GABA: an excitatory transmitter in early postnatal life. Trends Neurosci. 14, 515-519.

Cohen, D. and Yarom, Y. (2000). Cerebellar onbeam and lateral inhibition: two functionally distinct circuits. J. Neurophysiol. 83, 19321940.

Derdikman, D., Hildesheim, R., Ahissar, E., Arieli, A., and Grinvald, A. (2003). Imaging spatiotemporal dynamics of surround inhibition in the barrels somatosensory cortex. J. Neurosci. 23, 3100-3105.

Dickson, R. M., Cubitt, A. B., Tsien, R. Y., and Moerner, W. E. (1997). On/off blinking and switching behaviour of single molecules of green fluorescent protein. Nature 388, 355358.

Duarte, C. B., Ferreira, I. L., Carvalho, A. P., and Carvalho, C. M. (1993). Relation of exocytotic release of $\gamma$-aminobutyric acid to $\mathrm{Ca}^{2+}$ entry through $\mathrm{Ca}^{2+}$ channels or by reversal of the $\mathrm{Na}^{+} / \mathrm{Ca}^{2+}$ exchanger in synaptosomes. Pflügers Arch. 423, 314-323.
Duebel, J., Haverkamp, S., Schleich, W., Feng, G., Augustine, G. J., Kuner, T., and Euler, T. (2006). Two-photon imaging reveals somatodendritic chloride gradient in retinal ON-type bipolar cells expressing the biosensor Clomeleon. Neuron 49, 81-94.

Ebner, T. J., Chen, G., Gao, W., and Reinert, K. (2005). Optical imaging of cerebellar functional architectures: parallel fiber beams, parasagittal bands and spreading acidification. Prog. Brain Res. 148, 125-138.

Elias, S. A., Yae, H., and Ebner, T. J. (1993). Optical imaging of parallel fiber activation in the rat cerebellar cortex: spatial effects of excitatory amino acids. Neuroscience 52, 771-786.

Feng, G., Mellor, R. H., Bernstein, M., Keller-Peck, C., Nguyen, Q. T., Wallace, M., Nerbonne, J. M., Lichtman, J. W., and Sanes, J. R. (2000). Imaging neuronal subsets in transgenic mice expressing multiple spectral variants of GFP. Neuron 28, 41-51.

Freund, T. F. and Buzsáki, G. (1996). Interneurons of the hippocampus. Hippocampus 6, 347-470.

Grinvald, A. and Hildesheim, R. (2004). VSDI: a new era in functional imaging of cortical dynamics. Nat. Rev. Neurosci. 5, 874-885.

Hasan, M. T., Friedrich, R. W., Euler, T., Larkum, M. E., Giese, G., Both, M., Duebel, J., Waters, J., Bujard, H., Griesbeck, O., Tsein, R. Y., Nagai, T., Miyawaki, A., and Denk, W. (2004). Functional fluorescent $\mathrm{Ca}^{2+}$ indicator proteins in transgenic mice under TET control. PLoS Biol. 2, e163.

Helmchen, F. and Denk, W. (2005). Deep tissue two-photon microscopy. Nat. Methods 2, 932940.

Horikawa, J., Hosokawa, Y., Kubota, M., Nasu, M., and Taniguchi, I. (1996). Optical imaging of spatiotemporal patterns of glutamatergic excitation and GABAergic inhibition in the guineapig auditory cortex in vivo. J. Physiol. (Lond). 497, 629-638.

Inoue, T. and Krumlauf, R. (2001). An impulse to the brain-using in vivo electroporation. Nat. Neurosci. 4 Suppl, 1156-1158.

Isomura, Y., Sugimoto, M., Fujiwara-Tsukamoto, Y., Yamamoto-Muraki, S., Yamada, J., and Fukuda, A. (2003). Synaptically activated $\mathrm{Cl}^{-}$ accumulation responsible for depolarizing GABAergic responses in mature hippocampal neurons. J. Neurophysiol. 90, 2752-2756. 
Jedlička, P. and Backus, K. H. (2006). Inhibitory transmission, activity-dependent ionic changes and neuronal network oscillations. Physiol. Res. 55, 139-149.

Jose, M., Nair, D. K., Reissner, C., Hartig, R., and Zuschratter, W. (2007). Photophysics of Clomeleon by FLIM: discriminating excited state reactions along neuronal development. Biophys. J. 92, 2237-2254.

Kaila, K. (1994). Ionic basis of $\mathrm{GABA}_{A}$ receptor channel function in the nervous system. Prog. Neurobiol. 42, 489-537.

Katsuta, H. and Isa, T. (2003). Release from $\mathrm{GABA}_{\mathrm{A}}$ receptor-mediated inhibition unmasks interlaminar connection within superior colliculus in anesthetized adult rats. Neurosci. Res. 46, 73-83.

Kawa, K. (2003). Glycine receptors and glycinergic synaptic transmission in the deep cerebellar nuclei of the rat: a patch-clamp study. J. Neurophysiol. 90, 3490-3500.

Kitamura, K., Judkewitz, B., Kano, M., Denk, W., and Hausser, M. (2008). Targeted patch-clamp recordings and single-cell electroporation of unlabeled neurons in vivo. Nat. Methods 5, 61-67.

Klugmann, M., Symes, C. W., Leichtlein, C. B., Klaussner, B. K., Dunning, J., Fong, D., Young, D., and During, M. J. (2005). AAV-mediated hippocampal expression of short and long Homer 1 proteins differentially affect cognition and seizure activity in adult rats. Mol. Cell. Neurosci. 28, 347-360.

Kuner, T. and Augustine, G. J. (2000). A genetically encoded ratiometric indicator for chloride: capturing chloride transients in cultured hippocampal neurons. Neuron 27, 447-459.

Llinás, R. and Sugimori, M. (1980). Electrophysiological properties of in vitro Purkinje cell somata in mammalian cerebellar slices. J. Physiol. (Lond). 305, 171-195.

Mantamadiotis, T., Lemberger, T., Bleckmann, S. C., Kern, H., Kretz, O., Martin Villalba, A., Tronche, F., Kellendonk, C., Gau, D., Kapfhammer, J., Otto, C., Schmid, W., and Schutz, G. (2002). Disruption of CREB function in brain leads to neurodegeneration. Nat. Genet. 31, 47-54.

Mao, B. Q., Hamzei-Sichani, F., Aronov, D., Froemke, R. C., and Yuste, R. (2001). Dynamics of spontaneous activity in neocortical slices. Neuron 32, 883-898.
Marandi, N., Konnerth, A., and Garaschuk, O. (2002). Two-photon chloride imaging in neurons of brain slices. Pflügers Arch. 445, 357-365.

McCown, T. J. (2005). Adeno-associated virus (AAV) vectors in the CNS. Curr. Gene Ther. 5, 333-338.

Mihailoff, G. A. (1993). Cerebellar nuclear projections from the basilar pontine nuclei and nucleus reticularis tegmenti pontis as demonstrated with PHA-L tracing in the rat. J. Comp. Neurol. 330, 130-146.

Mrsic-Flogel, T., Hübener, M., and Bonhoeffer, T. (2003). Brain mapping: new wave optical imaging. Curr. Biol. 13, R778-R780.

Nabors, L. B. and Mize, R. R. (1991). A unique neuronal organization in the cat pretectum revealed by antibodies to the calcium-binding protein calbindin-D $28 \mathrm{~K}$. J. Neurosci. 11, 2460-2476.

Owens, D. F., Boyce, L. H., Davis, M. B., and Kriegstein, A. R. (1996). Excitatory GABA responses in embryonic and neonatal cortical slices demonstrated by gramicidin perforatedpatch recordings and calcium imaging. $\mathrm{J}$. Neurosci. 16, 6414-6423.

Paxinos, G. and Franklin, K. B. J. (2001). The mouse brain in stereotaxic coordinates, 2nd. ed., Academic Press, San Diego.

Payne, J. A., Rivera, C., Voipio, J., and Kaila, K. (2003). Cation-chloride co-transporters in neuronal communication, development and trauma. Trends Neurosci. 26, 199-206.

Pitkänen, A., Stefanacci, L., Farb, C. R., Go, G. G., LeDoux, J. E., and Amaral, D. G. (1995). Intrinsic connections of the rat amygdaloid complex: projections originating in the lateral nucleus. J. Comp. Neurol. 356, 288-310.

Pologruto, T. A., Yasuda, R., and Svoboda, K. (2004). Monitoring neural activity and $\left[\mathrm{Ca}^{2+}\right]$ with genetically encoded $\mathrm{Ca}^{2+}$ indicators. J. Neurosci. 24, 9572-9579.

Pond, B. B., Berglund, K., Kuner, T., Feng, G., Augustine, G. J., and Schwartz-Bloom, R. D. (2006). The chloride transporter $\mathrm{Na}^{+}-\mathrm{K}^{+}-\mathrm{Cl}^{-}$ cotransporter isoform-1 contributes to intracellular chloride increases after in vitro ischemia. J. Neurosci. 26, 1396-1406.

Prochnow, N., Lee, P., Hall, W. C., and Schmidt, M. (2007). In vitro properties of neurons in the rat pretectal nucleus of the optic tract. J. Neurophysiol. 97, 3574-3584. 
Rathenberg, J., Nevian, T., and Witzemann, V. (2003). High-efficiency transfection of individual neurons using modified electrophysiology techniques. J. Neurosci. Methods 126, 91-98.

Reiff, D. F., Ihring, A., Guerrero, G., Isacoff, E. Y., Joesch, M., Nakai, J., and Borst, A. (2005). In vivo performance of genetically encoded indicators of neural activity in flies. J. Neurosci. 25, 4766-4778.

Reuter, D., Zierold, K., Schröder, W. H., and Frings, S. (1998). A depolarizing chloride current contributes to chemoelectrical transduction in olfactory sensory neurons in situ. J. Neurosci. 18, 6623-6630.

Richerson, G. B. and Wu, Y. (2003). Dynamic equilibrium of neurotransmitter transporters: not just for reuptake anymore. J. Neurophysiol. 90, 1363-1374.

Sah, P., Faber, E. S., Lopez De Armentia, M., and Power, J. (2003). The amygdaloid complex: anatomy and physiology. Physiol. Rev. 83, 803-834.

Shinoda, Y., Sugihara, I., Wu, H. S., and Sugiuchi, Y. (2000). The entire trajectory of single climbing and mossy fibers in the cerebellar nuclei and cortex. Prog. Brain Res. 124, 173-186.

Sinnecker, D., Voigt, P., Hellwig, N., and Schaefer, M. (2005). Reversible photobleaching of enhanced green fluorescent proteins. Biochemistry 44, 7085-7094.

Somogyi, P. and Klausberger, T. (2005). Defined types of cortical interneurone structure space and spike timing in the hippocampus. J. Physiol. (Lond). 562, 9-26.

Soriano, P. (1999). Generalized lacZ expression with the ROSA26 Cre reporter strain. Nat. Genet. 21, 70-71.

Spergel, D. J., Kruth, U., Hanley, D. F., Sprengel, R., and Seeburg, P. H. (1999). GABA- and glutamate-activated channels in green fluorescent protein-tagged gonadotropin-releasing hormone neurons in transgenic mice. J. Neurosci. 19, 2037-2050.

Srinivas, S., Watanabe, T., Lin, C. S., William, C. M., Tanabe, Y., Jessell, T. M., and Costantini, F. (2001). Cre reporter strains produced by targeted insertion of EYFP and ECFP into the ROSA26 locus. BMC Dev. Biol. 1, 4.

Staley, K. J. and Proctor, W. R. (1999). Modulation of mammalian dendritic $\mathrm{GABA}_{A}$ receptor func- tion by the kinetics of $\mathrm{Cl}^{-}$and $\mathrm{HCO}_{3}^{-}$transport. J. Physiol. (Lond). 519, 693-712.

Szabadics, J., Varga, C., Molnár, G., Oláh, S., Barzó, P., and Tamás, G. (2006). Excitatory effect of GABAergic axo-axonic cells in cortical microcircuits. Science 311, 233-235.

Telgkamp, P., Padgett, D. E., Ledoux, V. A., Woolley, C. S., and Raman, I. M. (2004). Maintenance of high-frequency transmission at purkinje to cerebellar nuclear synapses by spillover from boutons with multiple release sites. Neuron 41, 113-126.

Telgkamp, P. and Raman, I. M. (2002). Depression of inhibitory synaptic transmission between Purkinje cells and neurons of the cerebellar nuclei. J. Neurosci. 22, 8447-8457.

Teruel, M. N., Blanpied, T. A., Shen, K., Augustine, G. J., and Meyer, T. (1999). A versatile microporation technique for the transfection of cultured CNS neurons. J. Neurosci. Methods 93, 37-48.

Thach, W. T. (1968). Discharge of Purkinje and cerebellar nuclear neurons during rapidly alternating arm movements in the monkey. J. Neurophysiol. 31, 785-797.

Thompson, S. M. and Gähwiler, B. H. (1989). Activity-dependent disinhibition. I. Repetitive stimulation reduces IPSP driving force and conductance in the hippocampus in vitro. J. Neurophysiol. 61, 501-511.

Verkman, A. S. (1990). Development and biological applications of chloride-sensitive fluorescent indicators. Am. J. Physiol. 259, C375-C388.

Wadiche, J. I., Amara, S. G., and Kavanaugh, M. P. (1995). Ion fluxes associated with excitatory amino acid transport. Neuron 15, 721-728.

Wei, F., Xia, X. M., Tang, J., Ao, H., Ko, S., Liauw, J., Qu, C. S., and Zhuo, M. (2003). Calmodulin regulates synaptic plasticity in the anterior cingulate cortex and behavioral responses: a microelectroporation study in adult rodents. J. Neurosci. 23, 8402-8409.

Wimmer, V. C., Nevian, T., and Kuner, T. (2004). Targeted in vivo expression of proteins in the calyx of Held. Pflügers Arch. 449, 319-333.

Zomot, E., Bendahan, A., Quick, M., Zhao, Y., Javitch, J. A., and Kanner, B. I. (2007). Mechanism of chloride interaction with neurotransmitter:sodium symporters. Nature 449, 726-730. 